A MICRO LEVEL ANALYSIS OF VIOLENT CONFLICT

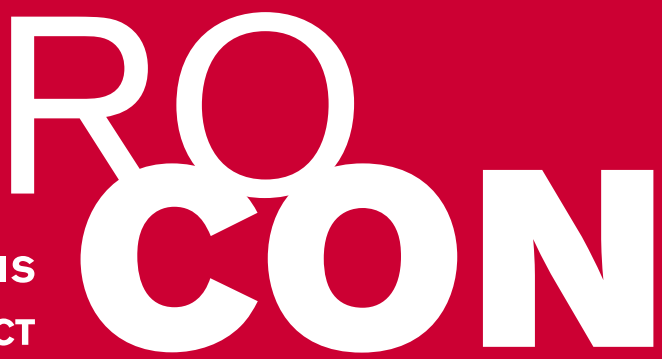

\title{
Institutions Under Construction: Resolving Resource Conflicts in Tanzanian Irrigation Schemes
}

MICROCON Research Working Paper 23

Els Lecoutere

January 2010 
Correct citation: Lecoutere, E. 2010. Institutions Under Construction: Resolving Resource Conflicts in Tanzanian Irrigation Schemes. MICROCON Research Working Paper 23, Brighton: MICROCON.

First published in 2009

(C) Els Lecoutere 2009

ISBN 9781858649161

For further information, please contact:

MICROCON: A Micro Level Analysis of Violent Conflict, Institute of Development Studies at the University of Sussex, Brighton BN1 9RE

Tel: +44 (0)1273 872891

Email: info@microconflict.eu

Web: www.microconflict.eu 


\title{
MICRONN
}

\section{Institutions Under Construction: Resolving Resource Conflicts in Tanzanian Irrigation Schemes ${ }^{1}$}

\author{
Els Lecoutere $^{2}$
}

MICROCON Research Working Paper 23

January 2010

\begin{abstract}
In present-day Tanzania, the increasing market penetration, the declining predictability of water availability and the intensifying institutional pluralism make small-scale irrigation schemes interesting for studying water governance institutions under construction. By documenting how conflicts over water are solved, we focus on how power enters this process. We also show that resource conflicts are not necessarily disruptive and that institutional pluralism can contribute to the development of more sophisticated resource governance institutions. But despite the potential of such processes to improve resource governance institutions, it can also reproduce deeply entrenched gender relations and hinder inclusion of less powerful resource users as they do not always have the capability to engage in conflict resolutions in a creative fashion.
\end{abstract}

Keywords: irrigation, power, resource governance institutions, Africa JEL: Q15, P48, O17, O55

\footnotetext{
${ }^{1}$ I acknowledge financial support from Ghent University and MICROCON. This research received research clearance from the Tanzania Commission for Science and Technology (COSTECH) and the Mufindi District Council. I am grateful for input and support from Björn Van Campenhout, Ben D’Exelle, Charles Kyando, Betty Mntambo and Incomet 2001. I wish to thank Koen Vlassenroot, Jeroen Adam and Anne Walraet for commenting on earlier drafts.

${ }^{2}$ Ghent University, Department of Third World Studies, Conflict Research Group. Email: els.lecoutere@ugent.be.
} 


\section{Resource Governance Institutions under Construction in Smallholder Irrigation}

\section{Schemes}

The increasing market penetration, the declining predictability of water availability and the institutional pluralism make small-scale irrigation schemes in Tanzania interesting laboratories to study local water governance institutions under construction. Agriculture in small-scale irrigation schemes supplements food production for many semi-subsistence farmers in rural Tanzania (Kaswamila and Masuruli, 2004). It becomes increasingly important for local marketing. For instance, production of tomatoes and onions for local marketing has expanded enormously over the last decade in several areas in Tanzania (Shao et al., 2002; Makoto, 2001) ${ }^{3}$. In addition, climate change and inter-annual climate variability such as ElNiño effects make rainfall less predictable and render rain-fed agriculture more risky (Dixon et al., 2003; Sokoni and Shechambo, 2005). Consequently, irrigated agriculture has become more attractive for food and cash crops. These trends drive up the value of land in irrigation schemes. In addition there is a growing need for more sophisticated water governance to deal with the increased competition.

Furthermore several policy changes have amplified legal and institutional pluralism and have made it more tangible at the lowest level of resource governance. Water governance in Tanzania has since its independence been characterized by legal and institutional pluralism, but post-colonial national policies for water governance have had little impact on the local level (Maganga, 2002). In smallholder irrigation schemes, water has principally been governed by user communities relying on 'traditional' institutions. Both the renewed national water policy (NAWAPO), based on integrated water resource management (IWRM) principles, and the water sector development strategy have introduced a new legal and institutional framework for water governance implying more implications on the local level (URT, 2002; URT, 2005a). In addition Tanzania has decentralized and has devolved more power, responsibilities and resources from the central government to local government authorities through the local government reform programme (URT, 2005b).

\footnotetext{
${ }^{3}$ Estimates point to an increase of fifty-eight per cent in the tomato production and an increase of fifteen per cent in the onion production in the rural Morogoro district over the period 1997-2002 (Shao et al., 2002).
} 
These recent developments have intensified the dynamics of making and remaking institutions for governing water in irrigation schemes on the local level. We believe it is important to uncover these local dynamics for several reasons. It can inform policy, counter neoMalthusian predictions of water wars, counterbalance the idea that the sole challenge lies in 'getting the institutions right' and downscale romanticized views about harmonious and inclusive local self-governance of natural resources.

In this article, we want to address three persistent fallacies about traditional resource governance institutions and their evolution, making use of data on how resource conflicts are solved in Tanzanian smallholder irrigation schemes. First, local institutions for governing water are often presumed to be a rather fixed set of 'rules of the game', but in reality these rules are constantly made and remade based on people's practices (Leach et al., 1999). Secondly we will weaken the widespread presumption that institutional pluralism is being systematically exploited in opportunistic ways. We will show that institutional pluralism can also be used in a creative way to resolve resource conflicts and can contribute to the development of more sophisticated resource governance institutions. Thirdly we will empirically demonstrate that power relations are central in pragmatic and creative conflict solving in institutional pluralist contexts. Additionally we will show that the least powerful do not have the capability to be that creative. We will do so by explicitly relating the way conflicts are solved to a direct measure of the relative power status of all parties involved in the conflict.

\section{Examining How Resource Conflicts Are Solved And Institutions Are Shaped}

An adapted empirical strategy is needed to study water governance and conflict management institutions that are shaped through users' practices. Mostly, processes that make and remake institutions are empirically substantiated through ex-post observation of institutions; consequently conclusions about processes at work are based on reconstructions or interpretations by stakeholders (e.g. Cleaver, 2002; Cleaver and Toner, 2006; Sehring, 2009 on institutional bricolage; Roth, 2009; Nuijten and Lorenzo, 2009 on legitimizing practices; Galvan, 2007 on institutional syncretism). These processes however can be deconstructed by uncovering the consecutive actions that follow resource conflicts, defined here as competing 
claims and disputes over access to or management of water and land ${ }^{4}$. Therefore, we take resource conflicts as the unit of analysis and investigate the way they are settled in order to disentangle various actor-driven processes of making and remaking institutions. Examples of partly case-based analysis of such processes include Ribot (2009) on legitimizing practices, Galvan (2007) on syncretism and Juma and Maganga (2005) on bricolage in 'bureaucratically' settled cases.

For data on resource conflicts, we could not rely on evidence from court cases. Given the institutional pluralist context, court cases only represent a fraction of conflict management (Maganga, 2002). Furthermore, the court is avoided by most smallholder irrigators as they often lack legal water rights. Therefore we collected data in five irrigation schemes on resource conflicts in the recent past and how they were solved. Individual, in-depth, semistructured interviews were conducted with irrigators involved in resource conflicts, village chairmen, village executive officers and, if present, irrigation scheme leaders ${ }^{5}$. The interviews included questions on the subject and severity of the conflict, users involved and the location of their plot in the irrigation scheme, timing and recurrence of the conflict, who monitored and mediated the conflict or who enforced rules and whether any sanctions were used. As this data was collected in a second visit, respondents were already familiar with the research and the research team and generally did not hesitate to talk about resource conflicts in their community ${ }^{6}$.

Secondly while applying a case-based analytical approach to study actor-driven processes of making and remaking local resource governance institutions, we will explicitly take into account the relative power status of the actors involved. The actors' power status and capabilities, power relations, and underlying structural characteristics of society such as the

\footnotetext{
${ }^{4}$ In our case study conflicts on water and land are not instances of violent mass conflicts defined as systematic breakdowns of the social contract resulting from and/or leading to changes in social norms, which involve mass violence instigated through collective action (Justino, 2007). Rather they are conflicts between individuals or between groups resulting from competing claims on resources and disputes over access to and management of resources. These conflicts do not result in mass violence but may imply violent encounters.

${ }^{5}$ Irrigators involved in resource conflicts were identified via individual surveys conducted in each of the five irrigation schemes. Most conflicts occurred less than five years prior to data collection. A few occurred ten to twelve years ago.

${ }^{6}$ The communities surveyed in this research were part of a broader research programme on access to resources, markets and micro-finance (see D’Exelle et al., 2009; Lecoutere et al., 2009; Van Campenhout et al., 2008).
} 
power structure or gender roles have been put forward as import variables in actor-driven negotiation processes that influence institutions and their making and remaking (Scoones, 2009). Leach et al. (1999) argue that in this regard an actor-oriented approach that takes an analysis of difference and an appreciation of power relations seriously, is essential.

Taking power relations seriously necessitates the unambiguous measurement of power of the actors involved. Power is a measure of one's ability to control his environment, including others' behaviour. The focus here is on the enabling nature of power, which relates to Sen's concept of capabilities, or Lukes' concept of 'power to' (Stewart and Deneulin, 2002, Lukes, 2005). Chambers (1997: in Gaventa and Cornwall, 2006) argues that power is more fixed in the people's relative position vis-à-vis others than in their persons. Social status for instance entails such relative positioning ${ }^{7}$. Weber already recognized social status as an important source of power and identified status as an effective claim to social esteem in terms of negative or positive privileges (Weber, 1922: in Weiss and Fershtman, 1998). Yet, assessing the actors' social status, power and capabilities on the basis of their productive identities such as 'farmers' or 'traders' or on their social roles such as 'leaders' or 'youth' is problematic because it is based on assumptions about the relation between status, power and those social positions that cannot be easily validated. Actors can have overlapping identities and social roles and their power and capabilities may depend on several other ascribed or achieved characteristics (Cleaver, 2002). That is why we use a direct measure of actors' relative power status and capabilities that is based on the community members' perception.

Our measure of the actors' relative power status was obtained by a participatory social status ranking exercise. Social status is a more commonly understood and unambiguous concept than power $^{8}$ and it is positively correlated with one's power status in society ${ }^{9}$. Common understanding and external validity of the concept was confirmed in post-ranking group

\footnotetext{
${ }^{7}$ Social status is a ranking of individuals in a given society based on their traits, assets and actions about which substantial agreement exist among different members of society (Weiss and Fershtman, 1998: 802).

8 'Hadhi ya jamii' and 'uwezo' were used as Swahili translations for social status. 'Hadhi ya jamii' literally means 'status in society' but is not widely used. When it is broadly interpreted, 'uwezo' not only means economic ability but also the ability to attain what one wants, the influence one can have on others, the ability to being listened to and to be respected. The notion of power is present in the term 'uwezo'.

${ }^{9}$ Only by exception the social power (of groups) does not commensurate with their social status (Lenski, 1984 in: Sachdev and Bourhis, 1991).
} 
discussions. For instance having a high social status is related to more decision power whereas having a low social status is linked to marginalization, limited self-determination, defencelessness and voicelessness.

In each of the five sites the participatory ranking exercise was organized as follows: after participatory mapping the irrigation scheme, a randomly assigned group of twenty irrigation scheme users was asked to identify a maximum of 100 users on the map. Four randomly composed subgroups of the twenty participants ranked the identified irrigators by putting name cards of each identified irrigator on a ladder with four rungs ${ }^{10}$. High (low) rungs represented high (low) social status (Lindemann, 2007) ${ }^{11}$. This resulted in (maximum) four rankings for each identified irrigator. Each ranking was transformed into a score, equal to the value assigned to the rung - one to the lowest rung, four to the highest - divided by the total number of rungs on the ladder (Van Campenhout, 2007). The mean of scores made up the irrigator's final social status score ${ }^{12}$. This final social status score is our measure of each irrigator's power status relative to other irrigators using the same irrigation scheme.

\section{Water Governance in Small-Scale Irrigation Schemes in Mufindi District, Tanzania}

The input for studying institutions for resource governance under construction will be conflicts over water in small-scale irrigation schemes in semi-arid rural Tanzania. In consultation with local experts on irrigated agriculture, five irrigation schemes in the semiarid lowland areas of Mufindi district were selected ${ }^{13}$. Mufindi district was chosen for this case study because of the importance of irrigated agriculture on both food and cash crops (Mkavidanda and Kaswamila, 2001; Majule and Mwalyosi, 2003; URT, 2006). The irrigation schemes are situated in the Rufiji river basin (see Figure 1).

\footnotetext{
${ }^{10}$ Participants were not expected to rank themselves nor users they were not well acquainted with.

${ }^{11}$ When the group thought less (more) than four social status categories could be distinguished, they were allowed to remove (add) rungs.

${ }^{12}$ The average social status score and standard deviation in respective irrigation sites is $0.65(0.21)$; 0.53 (0.21); 0.64 (0.19); 0.65 (0.15); 0.56 (0.22). On average the standard deviation between subgroups' rankings does not exceed 0.20 which indicates that subgroup consensus on the ranking is relatively high in every irrigation site.

${ }^{13}$ The altitude in the lowlands of Mufindi district ranges from 1,200 to 1,500 meters. There is an average annual rainfall of between 900 and 1,200 mm and this rainfall is unimodal and lasts from December until April (URT, 1999).
} 


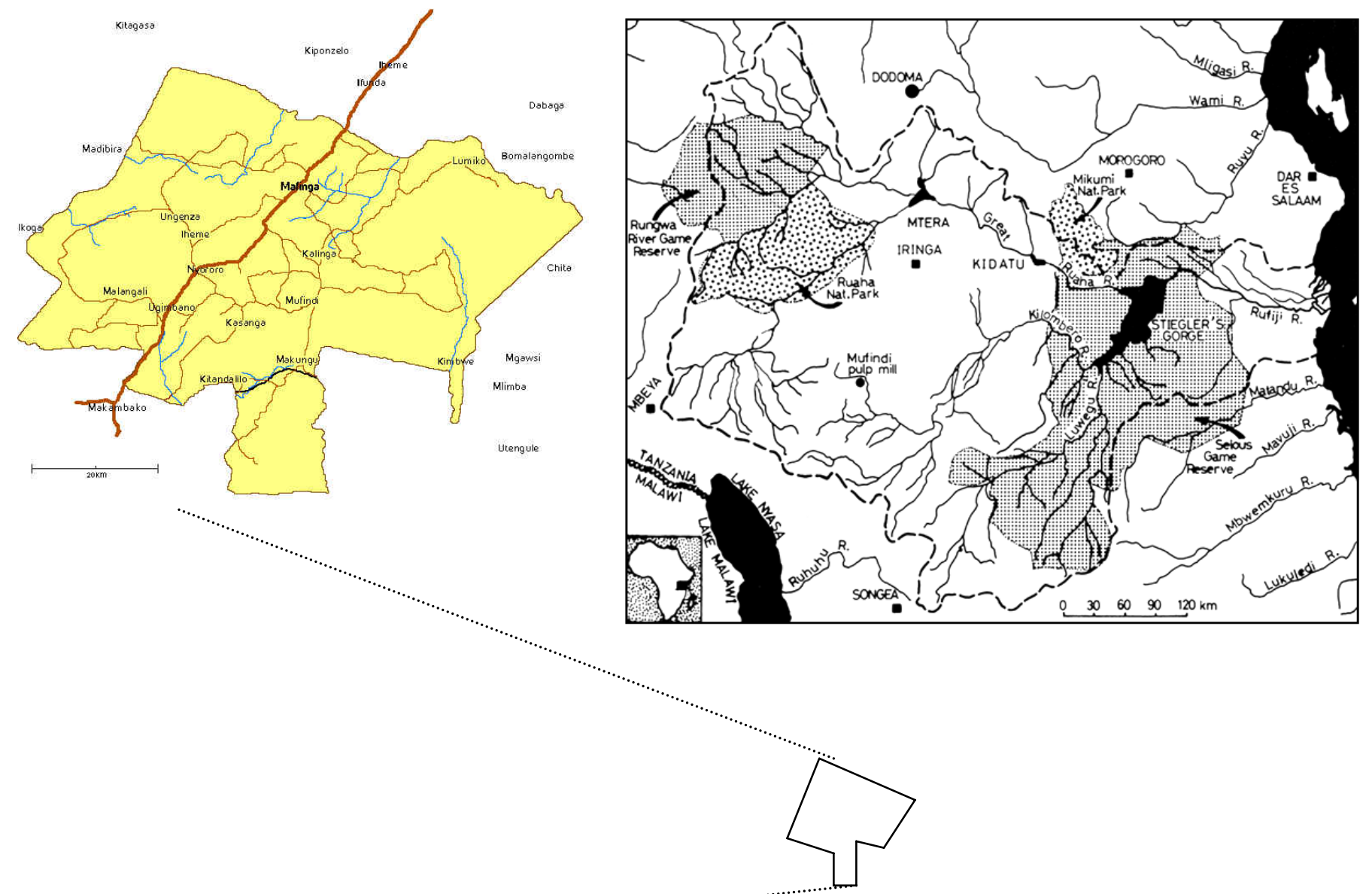

Source: Bernacsek, 1981

Cropping patterns in the five irrigation schemes selected are quite similar, with a mix of typical food crops such as maize and beans and cash crops for local marketing such as onions, tomatoes and other vegetables. The irrigation schemes are somewhat different in terms of infrastructure and its users ${ }^{14}$ :

${ }^{14}$ To assure anonymity we will use the following codenames: Mutua (Mt), Kitungulu (KitU), Isanu (Is), Ika (Ik) and Kitangzi (KitZ). 
- Irrigation scheme Mutua was developed about forty years ago. It is composed of two main canals diverted from a river, with plots along secondary and tertiary canals and used by about forty people.

- Irrigation scheme Kitungulu, used by approximately fifty people, consists of a canal that was originally constructed by colonial farmers but has been renovated about ten to twenty years ago. The farming plots have a slight slope and align secondary canals diverted from the primary canal, which is sourced by a river higher up hill.

- Irrigation scheme Isanu applies river-bed irrigation. It consists of a complex network of canals and diversions from the main river and from its feeding rivers. Some farming plots get irrigation water from river diversions and other plots from a canal dug recently and diverted from one of the feeding rivers. The irrigation scheme Isanu is used by about 100 farmers from the same village. Upstream and downstream there are similar networks of diversions and canals used by farmers from other villages ${ }^{15}$.

- Irrigation scheme Ika consists of primary and secondary canals sourced by three rivers that flow into the Ruaha river. At the bottom of the valley there is a network of diversions from the Ruaha river. Irrigation scheme Ika has been in use from 'time immemorial' and we have studied a section with about 100 irrigators from the same village. Upstream and downstream, other villages apply similar river-bed irrigation.

- Irrigation scheme Kitangzi practices river-bed irrigation and is a subsection of a valley with other irrigation schemes further downstream. Irrigation scheme Kitangzi is sourced by four rivers and consists of a complex network of diversions from the rivers and some bigger, recently dug canals. Approximately seventy irrigators from the same village farm in Kitangzi.

\footnotetext{
${ }^{15}$ The main river feeding Isanu and the upstream and downstream irrigation schemes eventually flows into the Ruaha river. The Ruaha river is used by various sectors and IWRM efforts try to reconcile needs while sustaining the river flow. In this regard, according to Isanu villagers and village leaders, plans have been made for a large-scale rice irrigation project further downstream. Isanu irrigators claim to have been told to abandon small-scale irrigation in favour of the rice project. This made Isanu irrigators suspicious about the aims of our research project but trust was eventually established after a lengthy discussion about our affiliation and objectives.
} 
Water governance and management of resource conflicts happen in a context of institutional pluralism in our irrigation schemes. In this respect we will sketch the relevant institutional frameworks. Broadly the 'bureaucratic' set of water governance institutions looks like this: on a national level there are the Ministry of Water and Livestock Development and the Water Resources Division. The National Water Policy (NAWAPO) (URT, 2002) and the National Water Sector Development Strategy (URT, 2005a) set out the formal rules and institutional framework for water governance. NAWAPO is based on IWRM principles and its objective is to come to a comprehensive framework to manage and use water resources 'optimally, sustainably and equitably' (URT, 2002). One of the intentions is to formalize informal water governance institutions. NAWAPO has not yet been incorporated into legislation and water management and water use is still regulated by Act No. 42 of 1974 as amended by Act No. 10 of 1981 and Act No. 17 of 1989. These acts stipulate that all water is vested in the United Republic of Tanzania and that abstraction of water for any purpose requires possession of a water right, which can be issued by the Basin Water Officer (Juma and Maganga, 2005; Mwakalila, 2005). On the basin level, Basin Water Boards and the executive Basin Water Offices coordinate IWRM, harmonize stakeholders and sectors, issue water rights, enforce water rights and pollution control measures and resolve conflicts. They can delegate responsibilities to catchment and sub-catchment water committees (URT, 2005a). The Rufiji Basin Water Office (RBWO), the relevant basin water office for our case study sites, is stationed in Iringa. An example of an RBWO by-law with a local impact is the prohibition to farm close to river banks in order to protect water sources. In principle, water user associations (WUA) should be the lowest levels of water resource management in the river basins with the responsibility to manage and plan equitable water use on the local level and to mediate in local water conflicts. WUA should hold a legal water right (Juma and Maganga, 2005; URT, 2005a). In reality few smallholder irrigators are organized in WUA or have a legal water right.

The renewed institutional framework on water governance does not explicitly assign a role for government on a district, ward and village level although district councils and local government authorities are supposed to be represented in basin water boards and (sub-)catchment committees. Yet, the local government reform programme resulted in decentralisation and a devolution of power, responsibilities and resources to district, ward and village government (URT, 2005b). This indirectly increased their involvement in water and land governance. On the district level, there are the district agricultural and livestock officers 
and irrigation officers that deal with irrigated agriculture and extension services. Stipulations issued by the district planning office - for instance on land use in river-beds - can also have repercussions on the irrigation scheme level. The district level however is not dealing with appropriation of water within irrigation schemes and there is no indication that any resource conflict has reached the district level ${ }^{16}$. Whether the village government level is involved in water governance depends on whether by-laws have been adopted. The village chairman (VC), village executive officer (VEO) and village council sometimes take decisions that deal with water provision and appropriation. They are regularly called to intervene in conflicts over water or land.

Although resource governance institutions in the studied irrigation schemes are in flux and have a high degree of local specificity, it is possible to identify some common principles of 'traditional' or 'informal' water governance institutions that deal with provision, appropriation and enforcement ${ }^{17}$. Irrigation water is provided through canals and river diversions. These are dug or maintained collectively or on the initiative of one or a few individuals. Usually, irrigators are expected to contribute to canal cleaning and maintenance every year. Fixed rules on the appropriation of irrigation water are largely absent, but generally, competition and distributive conflicts are avoided in order to maintain harmony in the community. Irrigators also strongly believe that everybody has a right to water. Often, irrigators individually decide on water appropriation. Sometimes they informally agree on water sharing or make up a rotation scheme. With regard to conflict management, we observe a clear preference for reconciliation over confrontation. Other than that, conflict management, rather than being based on well-defined institutions, relies on pragmatic and creative problem solving when disputes arise.

\section{Creativity And Power at Work: Solving Resource Conflicts in Smallholder Irrigation}

\section{Schemes}

Each of the following cases illustrates how resource conflicts are resolved in the context of resource governance institutions under construction. We examine the role of power relations

\footnotetext{
${ }^{16}$ Interview with Mufindi District Agriculture Extension Officer, Mr. Nko, Mafinga, 20 June 2008.

${ }^{17}$ Based on information gathered through interviews and group discussions with users of the studied irrigation sites.
} 
in solving conflicts and we relate to processes of actor-driven making and remaking of institutions in contexts of institutional pluralism.

\section{Power And Creative Conflict Solving With The Aid of Institutional Pluralism}

A conflict crops up in irrigation site Kitangzi when an upstream irrigator neglects to unblock the water flow after irrigating, which affects a downstream user. The affected downstream user, who claims to be the initiator of that canal, solves the problem through an informal talk with the upstream irrigator. In his defence, he refers to common practice in the irrigation scheme to unblock the canal after irrigating. In addition, he cites a NAWAPO guideline saying that 'every citizen has an equal right to access and use the nation's natural water resources for his and the nation's benefit' (URT, 2002:17) (case KitZ1). The affected user attended an RBWO training and readily applies his knowledge. He might also have needed the backing of more 'bureaucratic' rules in his dispute with the upstream user who has a slightly higher power status (power status resp. equal to 0.69 and 0.73 ).

Secondly the water flow of the same downstream user is affected by another incident. A female upstream irrigator neglects to redirect water to the canal and leaves water flow away (case KitZ2). The affected downstream user complains directly to the lady. This time he refers to a regulation established by the district planning office stipulating that the water flow should always return to its source. In addition he threatens to report to village leaders. The strategies by the affected user are sufficient to make the lady comply. The fact that the affected user is male and has a relatively higher power status than the lady may have contributed.

These cases already illustrate that, while pragmatically responding to resource problems, actors creatively blend elements of diverse institutions. While doing so, more bureaucratic institutions gain 'social embeddedness' as they are used as a reference, even when problems are solved outside the bureaucratic system. Cleaver (2002) refers to such practices as processes in which bureaucratic institutions become more 'socially embedded'. These fit in processes of 'institutional bricolage', which she defines as processes in which socially embedded actors respond in an ad hoc, creative yet also structurally constrained way to arising issues that regard natural resource governance whilst borrowing or constructing mechanisms for resource governance from existing institutions, styles of thinking and sanctioned social relationships (Cleaver, 2002:16). 
'Social embedding' also takes place when elements of institutions at hierarchically higher levels of bureaucracy are picked up at lower levels. In a first example from irrigation site Isanu, the village government tries to solve a potentially violent conflict over closing of the river's water intake (case Is 2$)^{18}$. The VC suspects the farmer, who closed the river intake so water would flow to the canal he initiated, 'to think the water is his and others have no right to use it' (VC, Isanu, 9 May 2009). To settle the dispute the village government uses a NAWAPO guideline stipulating that everyone has an equal right to water. Could it be that the NAWAPO guideline came in handy to overrule this relatively powerful canal initiator (power status equal to 1$)$ ?

Secondly a dispute arises in irrigation system Ika because somebody having a relatively high power status (equal to 0.81) digs a new canal in the river-bed in order to drain water from his plot which is too moist to farm (case $I k 3$ ). A group of downstream users, both irrigators and domestic water users, fear this will cause water shortages and soil erosion as water will have to find a new course. The group complains to the VEO. First, the VEO sends a written request to the offender to stop digging the canal. But this has little effect. After that, the village council is convened to decide on the issue. As the village has no appropriate by-laws, the RBWO prohibition on digging additional canals in the river bed is referred to and the village council imposes a fine on the farmer and summons him to fill the canal.

In the two preceding cases, village governments are actively engaged in institutional bricolage, absorbing rules established at hierarchically higher levels of bureaucracy in their set of working rules, contributing to 'social embedding' of these rules. Note that in both cases the offender is highly ranked in power status (resp. 1 and 0.81) which suggests that relying on rules established at higher levels may serve to gain leverage.

An additional interesting feature of the latter case is that although it may not have been a predetermined objective, resolving the conflict has boosted the village government's authority in water governance. In fact, the VEO praises the success in water governance: 'people now come to ask how to manage water and which rules to follow. The affected users thanked the village government for intervening' (VEO, Ika, 10 May 2009). The village government may

\footnotetext{
${ }^{18}$ This fits in a series of recurrent disputes between canal and river users in irrigation scheme Isanu (more details will follow).
} 
be - deliberately or not - engaged in legitimizing practices, a process that we will elaborate later on.

Oppositely, solving resource conflicts may instigate 'bureaucratization' of 'traditional', 'socially embedded' elements. For instance an irrigator in Mutua contests a lady's access to water while it was her turn to irrigate according to a rotation scheme (case Mt3). The irrigator uses the fact that she did not participate in canal cleaning as an argument to deprive her of water. This is also the reasoning of one of our sources reporting on the case (see case Mt6). This could be an (not necessarily deliberate) attempt to 'formalise' participation in canal cleaning as a condition for access to irrigation water. In a next section we will discuss other cases that gave occasion to formalizing informal agreements on water rotation or canal cleaning (e.g. case Is2, Is4, Is6).

Next, one of the parties involved in a dispute over an alleged illegal sale of land in irrigation scheme Kitungulu has used institutional pluralism to his advantage in a different way. One irrigator sold a plot of land he used but did not legally own to a semi-commercial farmer from a neighbouring town (case KitU5). When the former legal owner dies, an inheritor contests the sale and landownership of the semi-commercial farmer. The inheritor argues with the one who sold the plot and complains to the VC. The VC takes it into the village council, which decides that the plot belongs to the inheritor. The semi-commercial farmer however appeals to the ward tribunal that eventually decides the property right, including the alienation right, to the land goes to the person using the land if this had been fallow for more than twelve years. Thus according to the tribunal the sale was legal and the semi-commercial farmer rightfully acquired landownership. Strikingly the inheritor is convicted to paying compensation to the semi-commercial farmer ${ }^{19}$.

Institutional pluralism created the opportunity for the farmer involved in the land conflict to opportunistically search among the multiple sets of institutions for a way to solve the conflict with the highest chance of a satisfactory outcome. Such practices, inherent to situations of legal or institutional pluralism, are referred to as forum shopping (von Benda-Beckmann, 1981; Meinzen-Dick and Pradhan, 2002; Lund, 2006). Forum shopping is a negotiation

\footnotetext{
${ }^{19}$ One of the three sources reporting on this issue reported a slightly different version. She claims the tribunal decided the inheritor and semi-commercial farmer had to divide the plot of land. But the inheritor did not claim his half because he feared the semi-commercial farmer would kill him and compensated the semi-commercial farmer out of fear he would call the police.
} 
process in which actors' power relations matter a great deal and it is a strategy mainly of more powerful and generally better informed members of society (Meinzen-Dick and Pradhan, 2002).

The forum shopping semi-commercial farmer is indeed ranked relatively high in power status (power status equal to 0.75 ). The above may also indicate that not residing in the village and not belonging to the community leaves him more immune to social pressure to opt for more reconciliatory ways to resolve the land conflict (Hayami, 2009). There is still a general feeling in the community that land was not acquired in a rightful way and both the land seller and buyer are somewhat distrusted. The case clearly stuck in people's mind as three different sources including the VC report on it. This suggests that the semi-commercial farmer's strategy was exceptional because it was not socially acceptable.

Actual forum shopping is apparently not always necessary; threatening to do so may be an effective deterrent. For instance, in irrigation site Ika, an elderly lady and another irrigator quarrel because the latter opens the irrigation canal for too long which causes the lady's plot to flood and destroy the beans on her field (case Ik4). A (female) neighbour is called to mediate. She emphasizes the rotation scheme should be respected but also threatens to report the incident to the sub-village chairman (sub-VC). Eventually the offender agrees to close the canal. The fact that the affected elderly lady's power status is slightly higher than the offender's (resp. 0.54 and 0.43) may have contributed to winning her case.

Next, in irrigation scheme Kitangzi, a conflict arises and almost turns violent when two men compete to claim a vacant plot of land (case KitZ9). Elders are called to mediate. Later the village government is asked to intervene but it decides that the conflicting parties should settle the issue amongst themselves. According to a female water committee member, one of the claimants eventually renounces his claim to the plot because the other claimant's reputation made him fear an escalation. According to our source, the other claimant is 'a 'characterman', meaning he is intractable, is known to like conflicts, does not fear fighting and is not hesitant to go to court or call in the police' (Female irrigator and member of water committee, Kitangzi, 11 May 2009). It appears that fear for both violence and bureaucratic measures discouraged one of the competitors to further his case despite his relatively higher power status. Another interesting observation we will come back to is that village government has not taken the issue on board and did not take the opportunity to gain authority as legitimate judges over land conflicts in the irrigation scheme. 
Lastly in a case we already discussed, an affected user, a man with a relatively high power status, complains and threatens to report to village leaders if the offender, a lady, does not redirect water to the canal after irrigating (case KitZ2). His threat is effective.

Threatening to rely on better suitable or more 'bureaucratic' ways of conflict resolution has been an effective deterrent in the previous cases. In fact Aldashev et al. (2007) have argued that the mere threat of relying on a better suitable legal or institutional framework may well be enough to enforce a claim. Their model provides formal proof that the existence of a formal law enables people whose interests concur with this law, to threaten to use it and, under certain conditions and even without actually resorting to it, it may produce a more beneficial outcome. Aldashev et al. (2007) infer that groups marginalized by the 'traditional' legal framework may profit from pluralism because they can threaten to refer to the formal law that offers better protection. Yet in our cases this opportunity is taken by the more powerful and assertive community members rather than the marginalized members.

Ample creativity was required in the next series of related disputes in irrigation scheme Isanu. Recently an additional canal was dug on the initiative of a young and ambitious marketoriented farmer with a large plot in the irrigation scheme. Since the canal has been dug, competition over water between river users and canal users has caused grave disputes. A first incident was called 'a dangerous situation because a war could have started' by the VC (VC, Isanu, 9 May 2009) (case Is2). In fact, the canal initiator blocks the river intake to make water flow to the canal, thereby depriving river irrigators of water. Three of the most affected river irrigators complain to the canal initiator. When he warns the river irrigators not to close the water intake of the canal, the dispute almost turns violent. Other river irrigators observing the commotion report to the VC. As previously mentioned, the VC refers to the NAWAPO guideline on everybody's right to water. He reprimands the canal initiator and forbids him to close the water intake. The VC and VEO mediate between the conflicting parties. They reach an agreement on the water use, allocating water to the canal initiator on Sundays and to other irrigators on weekdays.

Later, one of the river irrigators obstructs the canal intake (case Is4). The canal initiator declares: 'we could have fought and killed each other' (Canal initiator, Isanu, 9 May 2009). Others warn the village government. The village extension officer mediates between the river irrigator and the canal initiator. He decides the river irrigator did not comply with the water use agreement and the prohibition to close each other's water intake. The river irrigator is 
sanctioned because he cannot compensate all that were affected; hence he has to pay a large fine. In addition the village extension officer instructs users to stick to the rotation scheme, which as a result becomes further 'bureaucratized'. Surprisingly, the sanctioned river irrigator is also made 'canal guard', a newly created function responsible for ensuring that the rotation scheme is respected. However it may indicate the sanctioned river irrigator's cooperation is ensured by co-opting him or else that the responsible function is a compensation for the fine. As such resentments are avoided, which fits into reconciliatory ways of conflict resolution.

Solving conflicts between river and canal irrigators in this irrigation scheme clearly demanded ingenuity. Both the rotation agreement and canal guard function are innovative water governance instruments in this setting. Solving the problems may have contributed to institutional syncretism, which is defined as 'a set of interpretive processes through which actors in local settings selectively transform newly imposed or transplanted institutional features (norms, rules, formal and informal organizational principles, and operational procedures) while adapting portable elements of pre-existing social institutions to produce innovative institutional configurations.' (Galvan and Sil, 2007:7). Institutional syncretism resembles institutional bricolage but entails that an innovative, original construction becomes the 'commonly' accepted institution (Galvan, 2007; Galvan and Sil, 2007). The rotation scheme in the above example seems to have been picked up as a 'rule of the game' but we have no information on whether this is the case for canal guarding ${ }^{20}$.

Still the conflict was lingering at the time of research and the water intake of the river and the canal are recurrently obstructed. The canal initiator explains that following the last incident he did not report to the village government (case Is7). Instead he reported to the RBWO while being aware that water appropriation by both river and canal users is illegal as they lack legal water rights. According to the canal initiator the RBWO told him to apply for a water right and has promised to improve the canal intake. Indirectly the RBWO has granted permission to canal irrigators to appropriate water, which is also how the canal initiator interprets it. Probably the canal initiator attempts forum shopping as another strategy to end his problems with river irrigators. He is secretive about it though, which may suggest he suspects his

\footnotetext{
${ }^{20}$ Ideally, before concluding on permanent and commonly accepted innovations, evidence of similar subsequent issues solved with reference to the innovative institution would be needed. Yet, the dynamic and ad hoc nature of problem solving may well produce other blends where (aspects of) the innovative institution is (are) just an element.
} 
strategy is socially not well accepted. Potentially his high power status makes him more immune to this (equal to 1).

The next examples show that also socio-political organizations try to do well out of solving conflicts. In irrigation site Kitungulu, there are recurrent disputes between a semi-commercial farmer from a neighbouring town and the irrigation user committee (IUC) (case KitU4, KitU6 and KitU8). The semi-commercial farmer does not participate in canal cleaning and he does not contribute to water right fees that the IUC is collecting ${ }^{21}$. First the semi-commercial farmer breaks an IUC regulation that makes water access conditional on canal cleaning. To solve the problem the IUC chairman and secretary talk to the farmer who apologizes. However, he still does not clean canals. Secondly the IUC already collects contributions as it is in the process of applying for a legal water right. The IUC chairman reports the farmer's refusal to contribute to the RBWO. The RBWO however advises the IUC chairman to report to the village government first. But the village government does not want to intervene as long as the farmer is not officially included in the list of irrigation users as submitted to the RBWO. They also demand that the IUC 'formalizes' its rules on canal management and on water use and presents these to village government. Moreover the village government refuses to endorse the IUC water right application to the RBWO. According to the VEO, the village government refuses because they fear the IUC will 'monopolize' the irrigation canal while the village government legally owns it. Another interpretation of these actions would be that the village government's refusal to endorse the IUC's water right application as well as their precondition to 'formalize' before intervening in conflicts fits into an attempt to 'reclaim' authority in governing the irrigation canal. They may want to position themselves as legitimate decision makers over property and as legitimate judges.

Next, remember the case in irrigation site Ika in which village government intervened when a farmer dug a canal to drain the water from a swampy plot of land causing water shortages downstream (case Ik3). The VEO boasted about the village government's success in gaining authority in water governance in the eyes of community members. Another conflict in Ika about closing a canal with sandbags, which will be discussed later, was reported to us by two sources, the mediator and the VC. Remarkably, each of them found it important to emphasize he was the one who solved the problem.

\footnotetext{
${ }^{21}$ The semi-commercial farmer is the one involved in the alleged illegal land sale (see case KitU5).
} 
The above examples fit into what Sikor and Lund (2009) call legitimizing practices that typically arise in circumstances with a multiplicity of institutions and are closely related to 'shopping forums', a process identified by von Benda-Beckmann (1981). Legitimizing practices entails socio-political organizations (representing certain institutions) seeking resource claims to authorize and disputes to solve in order to gain and sustain legitimacy in the eyes of their constituency and to turn their power into authority (Sikor and Lund, 2009). As successful legitimizing practices enable organizations representing particular institutions to gain or sustain authority and make it more likely that their commands or decisions will be obeyed by a given group of people, legitimizing practices are also seen as 'grounded practices of sovereignty' (Moore, 2005: in Sikor and Lund, 2009:7) and a form of 'agency from above' (Galvan, 2007).

Noteworthy is that none of the irrigation schemes in our case study operates with a legal water right, which implies all water appropriation is illegal according to national water laws. Still the village government intervenes in governance of 'illegally' appropriated water and engages in legitimizing practices.

Besides our case study shows that not all opportunities for legitimizing practices are seized. For instance when called upon to intervene because an irrigator refuses to contribute to water right fees, the RBWO advises to report to the village government first, rather than taking the issue on board (case KitU4). In another case the RBWO removes sandbags that obstruct the river intake during a routine visit but does not question the ones that put the sandbags there (case Ik2). A previously discussed example from irrigation scheme Kitangzi also points to unused legitimizing opportunities (case KitZ9). In that case the village government decided not to mingle in a dispute between competing claimants of a vacant plot of land.

\section{Power And Solving Conflicts The 'Traditional' Way}

Whereas various disputes over resources in the studied irrigation sites instigate processes of blending socially embedded and bureaucratic elements, processes of institutional syncretism, forum shopping and legitimizing practices, other disputes do not. They are solved according to 'traditional' or so-called 'socially embedded' rules of the game including 'informal' talks, settlements between families and the intervention of mediators.

For instance in irrigation scheme Mutua, a dispute starts because one user does not respect the rotation scheme, which has been informally agreed upon among irrigators. As a result another 
user - his sister - is deprived of water (case Mt2). She complains to her brother in person and they settle the dispute within the family. In the same irrigation scheme, another quarrel starts because a lady with a relatively low power status (equal to 0.25) does not participate in canal cleaning, which causes a reduced water flow for others (case Mt6). She is not sanctioned as she was not aware about the task but she is 'instructed' to participate in the future ${ }^{22}$. Previously we mentioned other cases in which the dispute is solved through personal talks (for example case KitZ1, KitZ2). But at times these were spiced up with references to NAWAPO or district planning office regulations or with threats to bring the issue to the village government.

Two other cases are apparently solved amongst users themselves. Two different incidents crop up in irrigation scheme Mutua because upstream users do not comply with the rotation scheme (case Mt7 and Mt8). Both issues are resolved after one of the affected downstream users personally complains to upstream users. Although the downstream user concerned claims he 'informally' talked to the upstream users as a fellow irrigator; he is also the VC, irrigation site leader and canal initiator and has a high power status (equal to 0.83). Regardless of the identity in which he approached the upstream users, his multiple functions most probably granted him authority, which he presumes to be good: 'As I am the chairman and the canal initiator, the man listened. If I would have been someone else, he might not have listened.' (VC, Mutua, 8 May 2009). Resolving the matter also likely reinforced the VC's authority. But this is not necessarily an example of deliberate legitimizing practices.

Sometimes mediators are called to settle conflicts. In irrigation scheme Isanu, a lady - the wife of a man with a high power status but who lives in discord with most of the other irrigators - obstructs the water flow in a secondary canal (case Is3). She puts downstream irrigators' tomatoes and other crops at risk. A mediator is called and the lady promises not to close the canal again. But she does not keep the promise. Later she moves to a nearby town.

Next, in Isanu, at the time workers were digging the canal a conflict starts between the canal initiator who is involved in previously mentioned disputes and a farmer whose plot the canal was supposed to pass through (case Is5). Two fellow irrigators, one of whom is the sub-VC, are called to mediate. After informal talks the canal initiator and the farmer agree that the

\footnotetext{
${ }^{22}$ Yet later her failure to clean the canal is used as an argument to deprive her of water (case Mt3) (see further).
} 
canal can pass the farmers plot if he can use the water as well. Later, the same persons have another dispute. While the canal initiator asked all canal irrigators to clean the canal, the farmer refuses and blocks the water flow (case Is6). Another irrigator notices the commotion and mediates between the conflicting parties. The issue is settled with a handshake and the mediator decides 'laws' should be made to manage canal cleaning.

In irrigation site Ika, a dispute arises between river users and two irrigators who close the intake of the river with sandbags to divert water to their irrigation canal. At the time of the conflict, there were no fixed rules on water use and people decided on the spot how to distribute water. Blocking each other's water flow however was unacceptable. One of our sources - a respected elder with a high power status (equal to 0.94) - states he was called by the affected users to mediate in this conflict. He says he convinced the offenders that others also needed water after which they removed the obstruction. The mediator claims this was the only intervention although the offenders feared other measures could be taken (case Ik1). But, according to the VC affected irrigators and domestic water users reported the issue to the village government. The VC says a village government delegation removed the sandbags and forbade the offenders to block the river intake. According to the VC, the respected elder was assigned to continue advising - and monitoring - the offenders (case Ik2). The 'true' story could not be uncovered but clearly, the VC finds it important to emphasize the village government's intervention whereas the elder highlights his role. Regardless of whom intervened in the dispute it seems that affected users called someone with considerable authority to deal with the offenders who have a relatively high power status (equal to 0.6 and $0.71)$.

Only in two cases a lady is called to mediate in a dispute. The first case has been described above (case Ik4). A female neighbour is asked to mediate in a dispute about a flooded plot. The issue is solved after the female neighbour threatens to call the sub-VC. Secondly an elderly lady is called to mediate when a fight breaks out between two male irrigators because one of them encroaches on the other's land to dig an additional irrigation canal (case Ik5). This lady states ‘women cannot mediate between men’ (Female irrigator, Ika,10 May 2009). Hence she refers them to the sub-VC. Eventually the dispute is solved by an intervention of the VEO and the village council. 
The examples used indicate that mediators generally do not use 'bureaucratic' instruments but stick to 'informal talks'. Another commonality is that nearly all mediators are powerful men ${ }^{23}$. Apparently women cannot mediate between men and the only female mediator uses the threat of calling upon bureaucratic measures. Besides, the male mediators often have multiple identities. They are irrigators in the same irrigation site as the conflicting parties and in most cases they are also sub-VC. In two of the three cases mediated by men, the offenders have a relatively high power status (man or wife with power status equal to 1) and probably the mediators' 'weight' is needed to deal with them.

The 'traditional' way to solve disputes through an intervention of a mediator however does not seem to be very effective. In most of the cases described here either offenders did not change their behaviour or the conflicting parties later were involved in another dispute, or the village government was also intervening. Does this mean the 'traditional' way to solve disputes by means of a mediator has reached its limits?

\section{Creative Conflict Solving: Not An Option for The Least Powerful}

Whereas all previously described conflicts are solved in one way or another and with more or less lasting success, in four cases conflicts are not really solved. They are simply stopped because the affected ones simply rest their case. In a first case production of a group of downstream irrigators is imperilled because two upstream irrigators disrespect water sharing agreements and extract water from the canal excessively (case Mt4). As one of those upstream irrigators is VC, irrigation leader and canal initiator and considered powerful - his power status equals 0.83 - the downstream users 'keep quiet whether their harvest is high or low' (IUC member, Mutua, 8 May 2009).

Secondly in irrigation site Kitangzi there is a dispute because an upstream user neglects to reopen the canal after irrigating her plot. There is no settlement of the dispute and two affected downstream users stop farming. One of the affected users formulates her reason for inaction like this: 'She is the wife of the bwana shamba (extension officer); so that is why I left it like that' (Female irrigator and member of water committee, Kitangzi, 11 May 2009) (case KitZ10).

\footnotetext{
${ }^{23}$ The power status of the mediator in case Is 3 is equal to 1 . In case Is 5 the mediators have power status equal to 0.63 and 0.88 .
} 
Another unsolved dispute involves a male relative who encroaches on a lady's plot of land in irrigation site Mutua (case Mt1). Although the boundaries of the plots are vague because they were divided at the time of heritage, the male relative does not respect the agreed division. Our source says the affected lady 'decides to keep quiet and stop the argument because the offender was a man and because they are relatives.' (Female irrigator, Mutua, 8 May 2009). In addition the man has a high power status, equal to 1 , whereas the lady has a low power status, equal to 0.33 . Eventually the affected lady just abandons her plot.

A different, quite vigorous and potentially violent conflict crops up in irrigation site Mutua when a male farmer denies a female farmer access to irrigation water despite an 'informal' agreement to take water in turns (case Mt3). One source, an IUC member (male), relates this dispute to the female farmer's failure to participate in canal cleaning, which betrayed trust between the two farmers (see case Mt6). According to this source their families try to reconcile and eventually reach an agreement on water sharing. Nevertheless the female farmer decides to stop farming. Commenting on the same dispute another source explains the female farmer did not complain to the offender nor did she call a mediator because: 'Nobody would be able to stop him from irrigating his field because he has the power of being a man', which implies 'he has the power to continue to irrigate if he decides to' (Female irrigator, Mutua, 8 May 2009). The female farmer is said to have stopped farming despite the advice to continue to provide for her family. Here as well the affected female farmer, with a low power status (equal to 0.25), faced a problem with a man considered among the most powerful on the irrigation site (power status equals 1).

There is one particular commonality in all four disputes that are not really solved but end because the affected parties have rested their case: the affected users are the least powerful of the conflicting parties. Apparently creative problem solving is out of their reach.

\section{Discussion: Resource Governance Institutions Under Construction And The Role of Power, Creativity And Institutional Pluralism}

The context of increasing resource values, rising competition and intensifying institutional pluralism is challenging resource governance institutions in smallholder irrigation schemes in rural Tanzania. Examining how conflicts over water and land are solved in this setting provides fascinating insights into local dynamics that shape more sophisticated resource governance institutions. 
First the local rules of the game for governing water and solving resource conflicts in an institutional pluralist context are not fixed. Governing water and land and solving resource conflicts rather happen pragmatically with actors responding in a creative but structurally constrained way to arising challenges. While doing so they liberally borrow from 'traditional' and 'bureaucratic' institutions or blend these. Cleaver (2002) has called such processes institutional bricolage.

Secondly contrary to the widespread belief that institutional pluralism is systematically exploited in opportunistic and suppressing ways through forum shopping and through legitimizing practices (von Benda-Beckmann, 1981; Sikor and Lund, 2009) our case studies show that institutional pluralism can also be creatively and constructively used to solve resource conflicts. Processes of institutional bricolage also imply that institutional pluralism can contribute to gradual development of more sophisticated local resource governance institutions (Leach et al., 1999; Cleaver, 2002). Since their development is shaped by the particular social and ecological context, they may be more locally meaningful than the imposed institutions are (Galvan, 2007).

Thirdly while every discipline has its pet agent responsible for shaping institutions, be it 'institutional engineers' or 'grassroot institutional ramshacklers', in reality both agency by organizations and agency by individuals contribute to it (Galvan, 2007). Many of the irrigators involved in resource conflicts are creative agents referring to elements of 'traditional' and bureaucratic institutions, calling in mediators, the village government or recently created water governance bodies. But there is also agency by organizations representing certain institutions: mediators, irrigation committees, the village government or the RBWO make use of elements of multiple institutional sets, sometimes while trying to gain authority in water or land governance.

Yet while creatively solving problems, neither individual creative agents nor organizational creative agents seem to shape institutions consciously and purposively. Pragmatism and a preference for reconciliatory solutions rather than confrontations are important drivers. Moreover, the way in which actors respond to arising issues depends largely on who is involved in the conflict and in conflict management, on their gender, on their character (for example the 'characterman'), on their objective for irrigating (for example sustenance or marketing), on their involvement in other incidents (such as serial offenders) and clearly also on the power status of all actors involved in the conflict. Also precedents and the history of 
the irrigation site itself determine to a large degree the way in which conflicts are solved. Our case study largely confirms Cleaver's propositions (2002).

Fourthly while many of the creative responses to local resource conflicts have been described in literature, our case study adds nuance to some of the theories on institutional bricolage, institutional syncretism, forum shopping and legitimizing practices. First, there are indications that in some cases 'socially embedded' 'traditional' ways to solve resource conflicts reach their limits. More bureaucratic ways to solve resource conflicts seem to be needed as leverage when dealing with relatively powerful offenders. Secondly while Aldashev et al. (2007) purport that threatening to use a better suitable legal framework can be advantageous for otherwise marginalized people, in our cases it is only the more powerful who use this strategy. Thirdly while sometimes socio-political organizations engage in legitimizing practices not all opportunities to do so are seized. Another crucial observation we will come back to is that creative problem solving is not accessible to everyone.

Our case study also highlights that power relations are of central importance for processes in which people's practices make and remake the 'rules of the game' (Leach et al., 1999). First actors' power status plays a role for compliance to rules, norms and agreements about water or land use. There are few cases where an irrigator with a low power status is the offender (i.e. six out of twenty-six different cases with information available on the actor's power status). Yet in half of the cases reported the rule breaker has a relatively high power status (14 of 26 cases). There are also two so-called 'serial offenders' both of whom have a relatively high power status. One of them is a semi-commercial farmer who does not reside in the village but in a neighbouring town. The other is a young, ambitious market-oriented and more widelytravelled farmer with a large plot in the irrigation scheme. However the question on whether they are flagrant offenders, not deterred by social sanctions, remains unanswered. Or are they scapegoats because they generate jealousy or because they are not fully integrated in the community?

A second observation on the actors' power status is that it is an important variable in different processes prompted by resource conflicts. In fact, irrigators with a relatively high power status are more inclined to engage in forum shopping and to threaten to do so. Purely socially embedded instruments to enforce rules or resolve conflicts are mainly employed when it concerns an offender with a relatively low power status. In cases regarding offenders with relatively high power status, mediators - elders or fellow irrigators and generally powerful 
men - are more likely to be deployed and these mediators often have an administrative function underpinning their authority. This need for leverage is also evident from the higher likelihood of relying on stronger, more authoritative and often more bureaucratic ways for conflict management if it concerns powerful offenders.

But the most striking observation with regard to power relations is that in four out of twentysix cases, the affected users rest their case because they are the least powerful of the conflicting parties or because they are women - even with a not so low power status. Low power status and female irrigators apparently do not always have the capability or forsake their capability to engage in creative conflict solving and do not uphold their interests. This shows that deeply entrenched power relations seriously limit the scope of institutional bricolage for the least powerful people in the community.

As far as policy is concerned, our case study shows that water or land conflicts are not necessarily disruptive; they can prompt constructive processes contributing to the development of more sophisticated institutions for the governance of water and land. However, to realize the potential of such constructive responses to local resource conflicts the dynamics of innovation, creative problem solving, locally adapted solutions and legitimation should be appreciated by policy makers (Meinzen-Dick and Pradhan, 2002; Galvan, 2007). While emphasizing local dynamics the role of the state in resource governance should also be acknowledged (Roth, 2009). Different state organizations act and interact with other local agents in a creative way. Hence these organizations should be allowed to flexibly interpret national legal and policy principles while responding to local resource challenges (Galvan, 2007). Building on the pragmatic and socially embedded nature of processes through which institutions governing water and land evolve at the local level can only enrich a policy aiming for meaningful, useful and politically inclusive sets of resource governance institutions.

However there is one major issue - such socially embedded local dynamics lack inclusiveness at one point. Women and the least powerful members of society are less capable to engage in creative problem solving and as a result they lose out when competition over water or land arises. As these power relations are deeply entrenched, tackling these constraints is one of the major challenges and responsibilities of policy makers trying to further develop local resource governance institutions. 


\section{References}

Aldashev, G., Chaara, I., Platteau, J.-P., Wahhaj, Z. (2007) 'An Economic Analysis of Legal

Pluralism', Paper presented at the ISNIE Conference on Comparative Institutional Analysis:

Economics, Politics, and Law, University of Iceland, Reykyavik (21-23 June),

http://www.isnie.org/assets/files/papers2007/platteau.pdf (accessed 9 October 2009).

Bernacsek, G. (1981) 'Freshwater fisheries and industry in the Rufiji River basin, Tanzania: the prospects for coexistence', in: Kapetsky, J. (ed.) Seminar on River Basin Management and Development, Blantyre (Malawi), 8-10December 1980. CIFA Technical Paper, 8: 69-88 .

Rome: FAO. http://www.fao.org/docrep/008/ad793b/AD793B03.htm\#ses2.1 (accessed 19 October 2009)

Cleaver, F., Toner, A. (2006) 'The evolution of community water governance in Uchira, Tanzania: The implications for equality of access, sustainability and effectiveness', Natural Resources Forum, 30: 207-218.

Cleaver, F., (2002) 'Reinventing Institutions: Bricolage and the Social Embeddedness of Natural Resource Management', European Journal of Development Research, 14 (2): 11-30.

D’Exelle, B., Lecoutere, E., Van Campenhout, B. (2009) 'Water Distribution in Africa: The Behavioral Relevance of Scarcity and Social Status', paper presented at the CSAE Conference 2009 on Economic Development in Africa, 22nd - 24th March 2009, Centre for the Study of African Economies, Oxford, UK. http://www.csae.ox.ac.uk/conferences/2009EDiA/papers/137-DExelle.pdf (accessed 7 January 2010)

Dixon, R., Smith, J., Guill, S. (2003) 'Life on the edge: Vulnerability and adaptation of African ecosystems to global climate change', Mitigation and Adaptation Strategies for Global Change, 8: 93-113.

Galvan, D. (2007) 'Syncretism and local-level democracy in rural Senegal', in D. Galvan and R. Sil (eds) Reconfiguring institutions across time and space. Syncretic responses to challenges of political and economic transformation, pp. 33-60. New York: Palgrave/Macmillan.

Galvan, D., Sil, R. (2007) 'The dilemma of institutional adaptation and the role of syncretism', in: D. Galvan and R. Sil (eds) Reconfiguring institutions across time and space. Syncretic 
responses to challenges of political and economic transformation, pp. 3-29. New York: Palgrave/Macmillan.

Gaventa, J., Cornwall, A. (2006) 'Challenging the Boundaries of the Possible: Participation, Knowledge and Power', IDS Bulletin, 37(6): 122-128.

Hayami, Yujiro (2009) 'Social Capital, Human Capital and the Community Mechanism: Toward a Conceptual Framework for Economists', Journal of Development Studies, 45(1): 96-123.

Juma, I., Maganga, F. (2005) 'Current reforms and their implications for rural water management in Tanzania', in: B. van Koppen, J. Butterworth and I. Juma (eds.) African Water Laws: Plural Legislative Frameworks for Rural Water Management in Africa. Proceedings of a workshop held in Johannesburg, South Africa, 26-28 January 2005. Pretoria: IWMI.

Justino, P. (2007) 'On the Links between Violent Conflict and Household Poverty: How Much Do We Really Know?’ MICROCON Research Working Paper, 1. Brighton: MICROCON http://www.microconflict.eu/publications/RWP1_PJ.pdf (accessed 20 October 2009)

Kaswamila, A., Masuruli, B. (2004) 'The Role of Traditional Irrigation Systems in Poverty Alleviation in Semi-Arid Areas: The Case of Chamazi in Lushoto District, Tanzania', REPOA Research Report, 04(3), REPOA, Mkuki na Nyota Publishers Ltd, Dar es Salaam

Lecoutere, E., D’Exelle, B.,Van Campenhout, B. (2009) 'Heterogeneity in Power Status and Its Effect on Rule Compliance in Self-governed Irrigation Systems', paper presented at the 13th Annual Conference of the International Society for New Institutional Economics, 18th$20^{\text {th }}$ June 2009, Walter A. Haas School of Business, University of California at Berkeley, USA. http://papers.isnie.org/berkeley.html (accessed 7 January 2010)

Lindemann, K. (2007) 'The Impact of Objective Characteristics on Subjective Social Position’, Trames, 11: 54-68.

Lukes S. (2005). Power: A Radical View, Basingstoke, Palgrave Macmillan.

Lund, C. (2006) 'Twilight Institutions: An Introduction', Development and Change, 37(4): 673-684. 
Maganga, F. (2002) 'The Interplay Between Formal and Informal Systems of Managing Resource Conflicts: Some Evidence from South-Western Tanzania', The European Journal of Development Research, 14(2): 51-70.

Majule, A., Mwalyosi, R. (2003) 'Enhancing agricultural productivity through sustainable irrigation. A case of vinyungu farming system in selected zones of Iringa', Research report submitted to ENRECA. Dar es Salaam, Tanzania: University of Dar es Salaam.

Makoto, K (2001) 'The Development Process of Commercial Tomato Production in the Iringa Region, Southern Highland, Tanzania', Journal of African Studies (Japan), 59: 33-52.

Meinzen-Dick, R., Pradhan, R. (2002) ‘Legal Pluralism and Dynamic Property Rights’, CAPRI Working Paper No 22. Washington, DC: IFPRI, http://www.capri.cgiar.org/pdf/capriwp22.pdf (accessed 9 October 2009).

Mkavidanda, T., Kaswamila, A. (2001) 'The role of traditional irrigation systems (vinyungu) in alleviating poverty in Iringa rural district', REPOA Research Report, 01(2), REPOA, Mkuki na Nyota Publishers Ltd, Dar es Salaam.

Mwakalila, S. (2005) 'Water Resources Management Guidelines in Ruaha Basin in Tanzania', in Lankford, B.A. and Mahoo, H.F. (eds) Proceedings of the East Africa Integrated River Basin Management Conference, 7th - 9th March 2005, Sokoine University of Agriculture, Morogoro, Tanzania. 195-208.

http://www.iwmi.cgiar.org/Research_Impacts/Research_Themes/BasinWaterManagement/RI PARWIN/PDFs/22\%20Mwakalila\%20SS\%20FINAL\%20EDIT.pdf (accessed 10 December 2009)

Nuijten, M., Lorenzo, D. (2009) 'Ruling by Record: The Meaning of Rights, Rules and Registration in an Andean Comunidad', Development and Change, 40(1): 81-103.

Okuno-Fujiwara Masahiro (2002) 'Social relations and endogenous culture', The Japanese Economic Review, 53(1): 1-24.

Ribot, J., (2009) ‘Authority over Forests: Empowerment and Subordination in Senegal’s Democratic Decentralization', Development and Change, 40(1): 105-129. 
Roth, D. (2009) 'Property and Authority in a Migrant Society: Balinese Irrigators in Sulawesi, Indonesia', Development and Change, 40(1): 195-217.

Sachdev, I., Bourhis, R. (1991) 'Power and Status Differentials in Minority and Majority Group Relations’, European Journal of Social Psychology, 21: 1-24

Scoones, I. (2009) 'Livelihoods perspectives and rural development', Journal of Peasant Studies, 36(1):171-196

Sehring, J. (2009) 'Path dependencies and institutional bricolage in post Soviet water governance', Water Alternatives, 2(1): 6181.

Shao, F., Nyomora, A., Mlay, E., Kasunga, N. (2002) 'Study on the horticulture development in Tanzania', Report for the Ministry of Agriculture and Food Security of the United Republic of Tanzania.

http://www.kilimo.go.tz/publications/swahili\%20docs/Cps\%20docs/Horti\%20Final\%20Report.pdf (accessed 9 October 2009).

Sikor T, Lund, C. (2009) ‘Access and Property: A Question of Power and Authority’, Development and Change, 40(1): 1-22.

Sokoni, C., Shechambo, T. (2005) 'Changes in the upland irrigation system and implications for rural poverty alleviation. A case of the ndiwa irrigations system, West Usumbara mountains, Tanzania', REPOA Research Report, 05(1), REPOA, Mkuki na Nyota Publishers Ltd, Dar es Salaam

Stewart, F., Deneulin, S. (2002) ‘Amartya Sen’s contribution to development thinking', Studies in comparative international development, 37(2): 61-70

United Republic of Tanzania (URT) (1999) Agro-ecological Zones and Farming Systems of the Southern Highlands of Tanzania. Dar es Salaam: Ministry of Agriculture, United Republic of Tanzania.

United Republic of Tanzania (URT) (2002) National Water Policy. Dar es Salaam, Tanzania: Ministry of Water and Livestock Development.

United Republic of Tanzania (URT) (2005a) National Water Sector Development Strategy. Dar es Salaam, Tanzania: Ministry of Water and Livestock Development. 
United Republic of Tanzania (URT) (2005b) 'Decentralisation for service delivery in Tanzania', paper presented by Mmari D., Permanent Secretary, President’s Office, Regional Administration and Local Government, United Republic of Tanzania at the conference on Building Capacity for the Education Sector in Africa, Oslo, Norway (12-14 October). www.lins.no/events/NETF05PaperTanzania.doc (accessed 16 December 2009).

United Republic of Tanzania (URT) (2006) National Sample Census of Agriculture 2002/2003. Small Holder Agriculture, Volume II: Crop sector - National report.

Van Campenhout, B. (2007) 'Locally Adapted Poverty Indicators Derived from Participatory Wealth Rankings: A Case of Four Villages in Rural Tanzania’, Journal of African Economies, 16(3): 406-438.

Van Campenhout, B., D’Exelle, B., Lecoutere, E. (2008) ‘Measuring Attitudes towards Risk in Rural Tanzania’ (mimeo)

http://www.ua.ac.be/main.aspx?c=bjorn.vancampenhout\&n=20840 (accessed 7 January 2010)

von Benda-Beckmann, K. (1981) 'Forum Shopping and Shopping Forums: Dispute Processing in a Minangkabau Village in West Sumatra', Journal of Legal Pluralism, 19: 11762.

Weiss, Y., Fershtman, C. (1998) ‘Social status and economic performance: a survey’, European Economic Review, 42: 801-820 